\title{
SOLID WASTE MANAGEMENT: A CRITICAL OVERVIEW OF INDIAN LEGAL REGIME
}

\author{
Dr Vikrant Sopan Yadav \\ Associate Professor, National Institute of Construction Management and Research, Hyderabad
}

Article DOI: https://doi.org/10.36713/epra8356

DOI No: 10.36713/epra8356

\begin{abstract}
Rapid industrialisation with poor check on pollution generation, unplanned and uncontrolled urbanisation and lack of public awareness and training are the greatest contributors of mounting size of solid waste generated by 1.3 billion population of India. It has resulted in danger to health and environment creating hurdles in path to sustainable development.

This research work is an attempt to analyse the laws regulating solid waste management in India. Author has analysed the duties of waste generators, Governments and local authorities in solid waste management. Author has also proposed few suggestions like, volunteers from public for reporting legal violations, sustainable consumption etc. for improved solid waste management.
\end{abstract}

KEYWORDS: Duty, Solid-waste, Environment, Management.

\section{INTRODUCTION}

As per the estimates published in Times of India, India tops the table of world's five municipal solid waste generators. With projected solid waste generation of 387.8 million tonne solid waste generation in 2030, India will be the highest solid waste generator followed by, USA (311 MT) and China (295 MT). In case of India, the figures are likely to jump to 543 MT solid waste in 2050. (Times News Network, 2020) "By 2047, it is expected that $1,400 \mathrm{sqkm}$ of landfill area would be required for dumping India's increasing volumes of municipal solid waste; this space is roughly equal to the combined area of three out of top five most populous cities in India: Hyderabad, Mumbai and Chennai." "ii (Annepu, 2012). This underlines the urgency necessitated in case of solid waste management. Only way to achieve the same seems to be effective enforcement of stringent laws and increased public awareness and participation.

The term solid waste has been defined as,

"...solid or semi-solid domestic waste, sanitary waste, commercial waste, institutional waste, catering and market waste and other non-residential wastes, street sweepings, silt removed or collected from the surface drains, horticulture waste, agriculture and dairy waste, treated bio-medical waste excluding industrial waste, bio-medical waste and ewaste, battery waste, radio-active waste generated in the area under the local authorities and other entities..." (Rule 2 (46), Solid Waste Management Rules, 2016).

Collection, processing and disposal of solid waste mainly lies within the domain of local bodies like village panchayats and municipal commissions. As right to environment is the fundamental right of Indian citizens, ${ }^{\text {iii }}$ these local bodies are "under the statutory obligation to scavange and clean the city and it is mandatory for these authorities to collect and dispose of the garbage waste generated from various sources in the city" ( $D r$ B. L. Wadhera v. Union of India $)^{\text {iv }}$

Justice MB Lokur said, "In case the states have the interest of the people in mind and cleanliness and sanitation, they should frame a policy in terms of the solid waste management rules so that the states remain clean. The attitude of the states/union territories in not yet framing a policy 


\section{EPRA International Journal of Research and Development (IJRD)}

even after two years is pathetic, to say the least." (India Legal, 2018) ${ }^{\mathrm{v}}$

Bharati Chaturvedi, founder and director of Delhi-based NGO Chintan which works on environmental justice "Construction and demolition (C\&D) waste is a huge problem, and adds significantly to air, water and soil pollution. The construction industry, if it meets all the norms including Environmental Impact Assessment (EIA) etc, should be held accountable for the urban challenge it creates.",vi

\section{CURRENT LEGAL REGIME IN INDIA}

The first comprehensive solid waste management rules were passed in 2000. Thereafter, poor implementation led to wide scale criticism (Times of India 2016; Hindustan Times 2016). ${ }^{\text {vii }}$ As a result, the Ministry of Environment revised in the rules 2016 . Hence, the latest solid waste management rules in 2016, to govern effective collection and disposal of municipal solid waste in India were brought in to force.

\section{DUTIES OF WASTE GENERATORS}

Rule 4 of Solid Waste Management Rules, 2016 imposes duty on every waste generator to,

- segregate and store the waste generated by them in three separate streams namely biodegradable, non-biodegradable and domestic hazardous wastes

- handover segregated wastes to authorised waste pickers or waste collectors

- wrap securely the used sanitary waste like diapers, sanitary pads etc., in the pouches provided by the manufacturers or brand owners of these products or in a suitable wrapping material and place the same in the bin meant for dry waste or non- bio-degradable waste;

- store construction and demolition waste separately as per the Construction and Demolition Waste Management Rules, 2016

- store horticulture waste and garden waste generated from his premises separately.

- Not to throw, burn or burry the solid waste generated by him, on streets, open public spaces outside his premises or in the drain or water bodies.

Other duties imposed under the rules includes, intimation of gatherings of more than one hundred persons to local bodies and ensuring segregation of waste (Rule 4 (4)); street vendor to keep suitable containers for storage of waste and its deposit in storage depot or container or vehicle (Rule 4 (5)); segregation of waste and handover recyclable material to either the authorised waste pickers or the authorized recyclers by gated communities and institutions with more than 5,000 sq. metre area (Rule
4 (7)) etc. Similar duty of segregation, deposit of solid waste and processing of bio-degradable waste is imposed on hotels and restaurants. (Rule 4 (8))

\section{DUTIES OF STATE \\ GOVERNMENT/UNION TERRITORY}

Rule 11 of the Solid Waste Management

Rules, 2016 provides for numerous duties to be performed by the state governments. They are;

a) "The Secretary, Urban Development Department (UDD) in the State Government shall prepare policy for solid waste management.

b) Policy emphasis on waste reduction, reuse, recycling, recovery and optimum utilisation of various components of solid waste.

c) Ensure implementation of these rules by all local authorities

d) Town planning department to ensure that master plan of every city provides for setting up of solid waste processing and disposal facilities.

e) identify and allocate suitable land for processing and disposal facilities for solid wastes.

f) Town planning department to ensure a separate space for segregation, storage, decentralised processing of solid waste

g) The developers of Special Economic Zone, Industrial Estate, Industrial Park to earmark at least five percent of the total area of the plot or minimum five plots or sheds for recovery and recycling facility.

h) Facilitate establishment of common regional sanitary land fill for a group of cities/towns within a distance of $50 \mathrm{~km}$

i) Arrange for capacity building of local bodies in managing solid waste, segregation and transportation or processing

j) Notify buffer zone for the solid waste processing and disposal facilities." (Rule 11, the Solid Waste Management Rules, 2016)

\section{DUTIES OF LOCAL AUTHORITIES}

Rule 15 of the Solid Waste Management Rules, 2016 provides detail list of duties of local authorities which includes;

a) prepare a solid waste management plan

b) arrange for door to door collection of segregated solid waste from all households

c) establish a system to recognise organisations of waste pickers or informal waste collectors and promote and establish a system for integration of them

d) facilitate formation of Self Help Groups, provide identity cards 


\section{EPRA International Journal of Research and Development (IJRD)}

e) frame bye-laws incorporating the provisions of these rules

f) prescribe from time to time user fee to be paid by waste generator

g) direct waste generators not to litter i.e throw or dispose of any waste

h) setup material recovery facilities or secondary storage facilities with sufficient space for sorting of recyclable materials

i) establish waste deposition centres for domestic hazardous waste and give directions for its disposal

j) ensure safe storage and transportation of the domestic hazardous waste

Apart from afore mentioned, the local authorities also have duty to create public awareness, community involvement in solid waste management, facilitating construction waste management, educating and training workers etc. (Rule 15, Solid Waste Management Rules, 2016)

\section{CRIMINAL LAW}

The Indian penal code 1860 in chapter XIV provides for 'offences affecting public health, safety, convenience, decency and morals.' Improper disposal of solid waste results in environmental pollution, thereby posing threat to the life of prople in the vicinity. Hence, a criminal case can be filed against those who have caused the generation and improper disposal of solid waste.

Similarly section 133 of Code of Criminal Procedure 1973 (CrPC) provides for 'removal of nuisance,

In, Municipal Council, Ratlam v. Vardichand and Ors., viii commenting upon section 133 of $\mathrm{CrPC}$, the SC of India observed that,

"...the guns of Section 133 go into action wherever there is public nuisance. The public power of the Magistrate under the Code (CrPC) is a public duty to the members of the public who are victims of the nuisance, and so he shall exercise it when the jurisdictional facts are present as here., ${ }^{\text {,ix }}$

Use of the term nuisance (something annoying/causing inconvenience) indicates that section 133 of CrPC can be enforced even in case of solid waste management as it is likely cause nuisance to health and environment. The US Public Health Service has identified 22 human diseases that are linked to improper solid waste management (MIT Urban Development Sector Unit 1999). ${ }^{\times}$

In Re: Outrage as Parents End Life After Childs Dengue

SC levied a fine of Rs. 500,000 on the State of Andhra Pradesh and Rs. 300,000 each on the States of Madhya Pradesh, Maharashtra, Odisha, Uttarakhand and the Union Territory of Chandigarh on account of their failure to submit their respective
State/ Union Territory solid waste management policy in furtherance to the rules of 2016.

Criticising the lacklustre attitude of the aforesaid State/ Union Territory Governments, SC ordered the cessation of construction activities till the solid waste management policy framed by the aforementioned states and union territory.

\section{SUGGESTIONS}

Following suggestions are proposed, In order to improve the solid waste management in the country;

1. Central and state policy framework shall focus on reuse, resale or donation of solid waste.

2. Wherever possible, use of material likely to pollute environment or result in increased waste should be avoided. Active use of such material shall be rewarded with monetary benefits and awards.

3. Tax incentives should be given to gated communities and institutions for adopting minimal waste generating practices.

4. Cleanliness inspectors and volunteers from public (as done in Israel) be appointed for reporting the violation of solid waste management norms. Special training of law be given to such law enforcers.

5. Increase the number of recycling, solid waste collection and processing centres to be established and maintained by local bodies out of cleanliness and environmental cess.

6. Exemplary fines be imposed for violation of policy norms. Licenses/registration of entities/institutions may be cancelled in case of frequently defying policy norms.

\section{CONCLUSION}

Present generation had no control on the environment they inherited from forefathers but they can definitely control which one they want to hand over to the future generations. Effective solid waste management plays a crucial role in clean environment. Hence, it holds the key to sustainable future. India being the largest solid waste generator, has an uphill task to manage and dispose of the same without causing harm to health and environment. Solid Waste Management Rules revised in 2016 enlist the details duties of both solid waste generators and governments. However, how effectively these norms are being implemented remains a subject of wide scale research. Effective monitoring by Central Pollution Control Board and State Pollution Control Boards, stricter judicial check by Green Tribunals/higher judiciary and wide spread infrastructure for collection and processing units holds the key to effective waste management. Public 
awareness and engagement, incentives for better policy implementation are also the need of an hour.

\footnotetext{
${ }^{i}$ Times News Network. (2020, March 04). In 30 Yrs, India Tipped to Double the Amount of Waste it Generates. Retrieved from Times of India: https://timesofindia.indiatimes.com/india/in-30-yearsindia-tipped-to-double-the-amount-of-waste-itgenerates/articleshow/74454382.cms ii Annepu, $R K$ (2012). Sustainable Solid Waste Management in India. Columbia University Earth Engineering Center, pp 4-6, 44-89,

http://www.seas.columbia.edu/earth/wtert/sofos/Sustainabl e\%20Solid\%20Waste\%20Management\%20in\%20India_Fi nal.pdf

iii Municipal Council, Ratlam v. Vardhichand, (1980) 4 SCC 162; B.L. Wadhera v. Union of India and Ors. (1996) 2 SCC 594

${ }^{i v}$ B.L. Wadhera v. Union of India and Ors. (1996) 2 SCC 594

$\checkmark$ India Legal. (2018, September 16). Solid Waste Management: Waste of a Building. Retrieved from India Legal: $\quad$ https://www.indialegallive.com/cover-storyarticles/focus/solid-waste-management-waste-building/ ${ }^{v i} I d$

vii Times of India (2016): Waste Accumulates as Locals Protest Dumping at Ramna, http://timesofindia.indiatimes.com/city/varanasi/Wasteaccumulates-as-locals-protest-dumping-at-

Ramna/articleshow/51632267.cms; Hindustan Times (2016): Gone to Waste: How India is drowning in Garbage, http://www.hindustantimes.com/india/india-scities-are-faced-with-a-severe-waste-managementcrisis/story-vk1Qs9PJT8l1bPLCJKsOTP.html.

viii Municipal Council, Ratlam v. Vardichan and Ors. AIR 1980 SC 1622, (1980) 4 SCC 162

${ }^{i x}$ Para 9

${ }^{x}$ MIT Urban Development Sector Unit (1999): What a Waste: Solid Waste Management in Asia, East Asia and Pacific region, $p 20$ http://web.mit.edu/urbanupgrading/urbanenvironment/reso urces/references/pdfs/WhatAWasteAsia.pdf.
} 